\title{
Comparison of IQ scores between children with phenylketonuria and healthy children referring to Besat Hospital in Sanandaj between 2017 and 2018
}

Asadollah Fatholahpuor ${ }^{1}$, Sima Alimoradi ${ }^{2}$, Fayegh Yousefi ${ }^{3,4}$, Hajar Kashefi ${ }^{5}$

1. Assistant Professor of Pediatric Endocrinology \& Metabolism, Department of Pediatrics, School of Medicine. Cancer and Immunology Research Center Besat Hospital Kurdistan University of Medical Sciences, Sanandaj, Iran.

2. GP. Medical Faculty, Kurdistan University of Medical Sciences, Sanandaj, Iran. ORCID ID: 0000-0003-4089-7951

3. Associate Professor of Child Psychology, Department of Psychiatry, Kurdistan University of Medical Sciences, Sanandaj, Iran.

4. Social Determinants of Health Research Center, Research Institute for Health Development, Kurdistan University of Medical Sciences, Sanandaj, Iran (Correspond Author). Email.fykmsu@gmail.com. ORCID ID: 0000-0001-5503-3326

5. Research Center for Environmental Determinants of Health (RCEDH), Kermanshah University of Medical Sciences, Kermanshah, Iran.

\begin{abstract}
Background and Aim: Phenylketonuria is a type of autosomal recessive congenital and genetically induced fungal disease that has not been converted to tyrosine by the lack or lack of the phenylalanine hydroxylase enzyme and has been shown to increase phenylalanine levels in the blood, especially in the brain. The aim of this study was to compare the IQ scores of children with phenylketonuria and healthy children referring to Besat hospital clinic in Sanandaj in 2017-2018.

Methods: This historic cohort study was performed on all of the patients at the time of birth, referred to PKU and pediatric clinics, as well as healthy children (for phenylketonuria) referred to other clinics of the children's hospital. The control group was done. Goodinow's intelligence test was used to measure cognitive, mental and children's intelligence. Finally, the results of the two groups were analyzed by the statistical consult.

Results: The results showed that $46(69.7 \%)$ were male and $20(30.3 \%)$ were female. The mean age of the subjects was $6.34 \pm 2.52$ of years. Result from the current study showed that there was not significant differences between IQ mean in two groups of study ( $p>0.05$ ).

Conclusion: According to the results of this study, the timely identification and treatment of patients with phenylketonuria has been able to prevent the complications of this disease to a large extent, and keep the children's IQs intact, thereby providing timely and accurate identification and treatment of this disease is necessary among children.
\end{abstract}

Key words: PKU, IQ, Children

Received: April 22, 2019

Accept: July6, 2019

How to cite the article: Asadollah Fatholahpuor, Sima Alimoradi, Fayegh Yousefi, Hajar Kashefi.
Comparison of IQ scores between children with phenylketonuria and healthy children referring to
Besat Hospital in Sanandaj between 2017 and 2018. SJKU 2019; 24 (5): 12-21

Copyright (C) 2018 the Author (s). Published by Kurdistan University of Medical Sciences. This is an open access article distributed under the terms of the Creative Commons Attribution-Non Commercial License 4.0 (CCBY$\mathrm{NC}$ ), where it is permissible to download, share, remix, transform, and buildup the work provided it is properly cited. The work cannot be used commercially without permission from the journal. 
مقايسه نمر ات بهره هوشى كودكان مبتلابه فنيل كتو نورى با كودكان سالم مراجعه كننده به

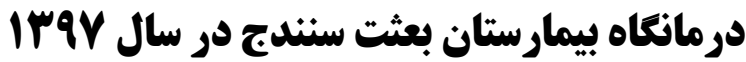

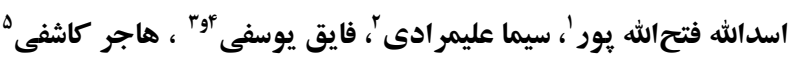

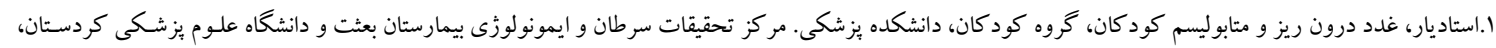
ستندج، ايران

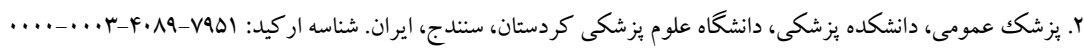

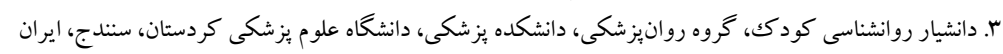

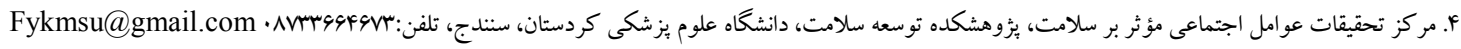

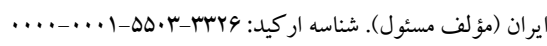

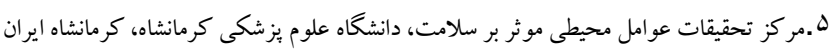

جָكيله زمينه و هدف: فنيل كتونوريا نوعى بيمارى سوختوسازى مادرزادى و زنتيكى از نوع اتوزومال مغلوب است كه به علـت كمبود

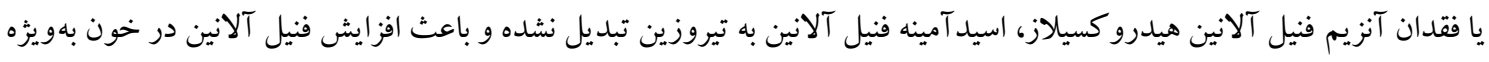
در مغز مى شود. هدف مطالعه؛ مقايسه نمر ات بهره هوشى كود كان مبتلابه فنيل كتو نورى با كود كان سالم مر اجعه كننده به درمانحاه

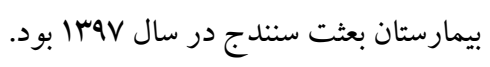

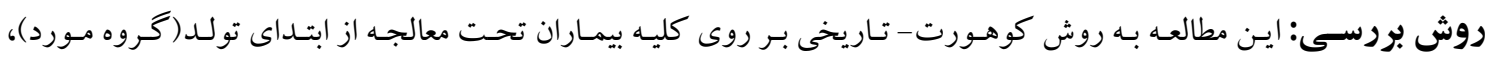

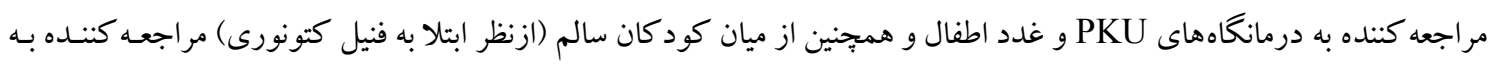

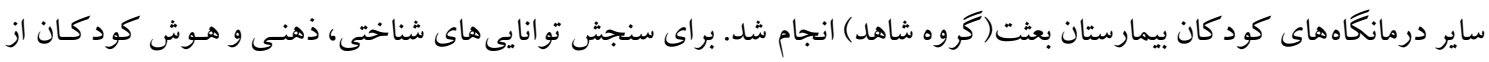

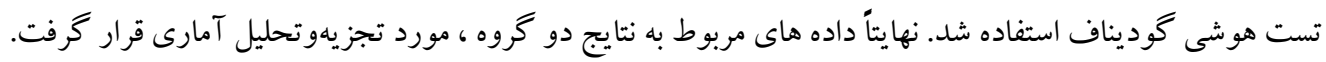

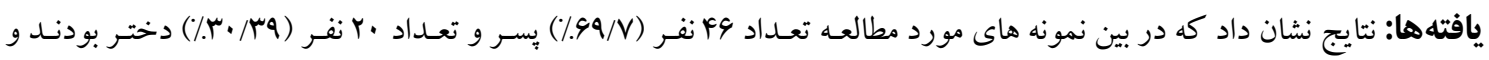

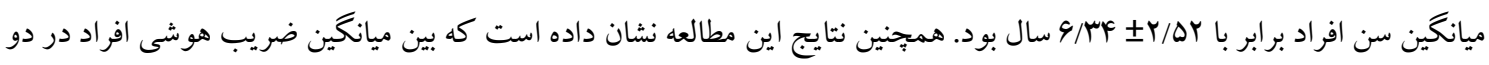

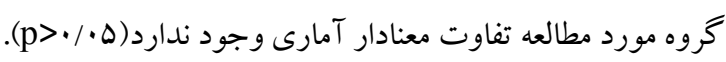

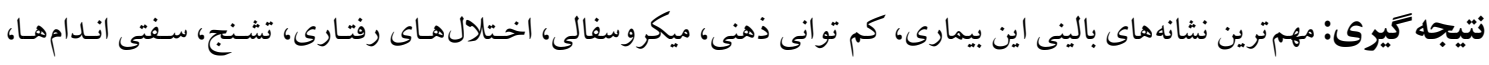

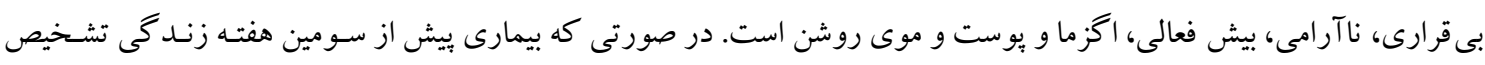

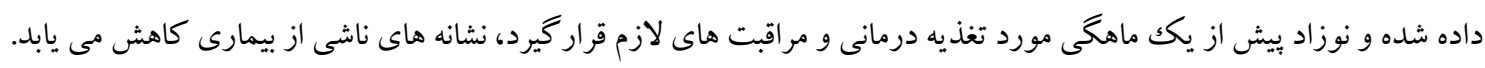
كلمات كليدى: فنيل كتونوريا، بهره هوشى، كود كان وصول مقاله:QN/Y/Y 
و سوم اينكه ميزان شيوع هاييرفنيل آلانينمى در حسدود ..1 مورد در هريكك ميليون تولد زنده است. شيوع بيمـارى فنيل

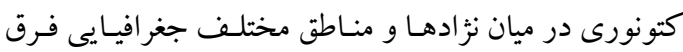
دارد. بيشترين بيمارى در ميان ايرلندىها و كمترين ميزان در ميان زاينىها گزارش شده است.اين بيمارى ،در سياهيوستان بسيار نادر است(Y). فراوانى PKU در قفقازىهـا ا مـورد در

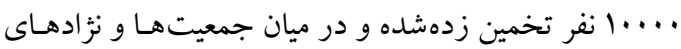
ديخر تغيير است(F). در مطالعه ديخـرى در شيراز از تـاريخ ITV9

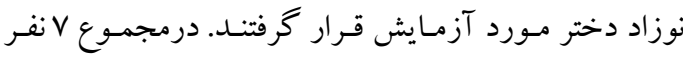

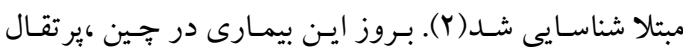

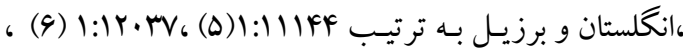

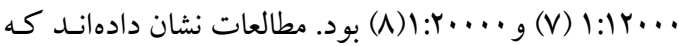
بهوطو كلى تعداد ازدواجهاى فاميلى در منطقه مديتر انه و در

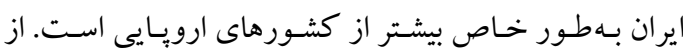

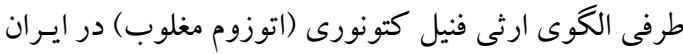

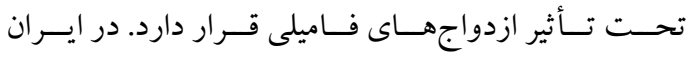

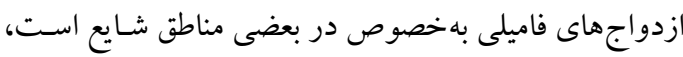

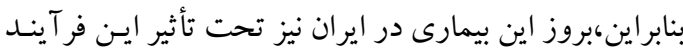

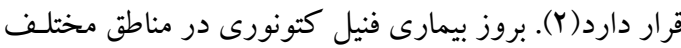
ايران موردبررسى قرار گرفته است. بهعنو انمثال، در مطالهـه

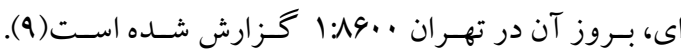

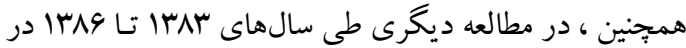

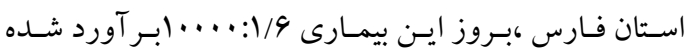
اسـت( •1). در اصـفهان نيـز از ميـان تعـداد الباد 1911 بيمـار

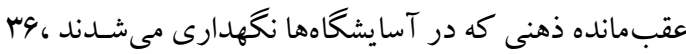
نفر (זدرصد) به PKU مبتلا بودند و بر اساس گزارش مركز

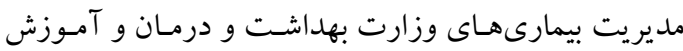

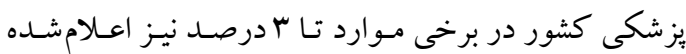

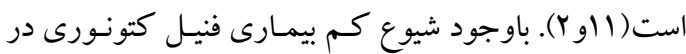

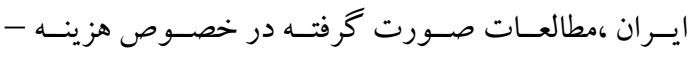

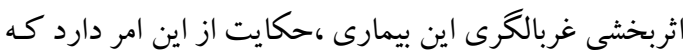

مقدمه فنيل كتونورى (PKU: OMIN 261600) (1)، ،شايعترين اختلال زنتيكى مو جود در متابوليسـم اسـيد آمينهاسـت ،كـه توارث اتوزمال مغلوب دارد. در اثر اين نقض آنزيمى ،فنيـل

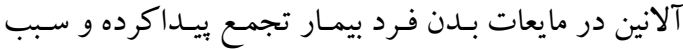
رســوب آن در منــاطق مختلفــى همجِـــون بافـت مغــز

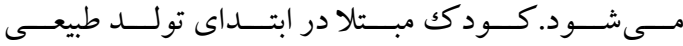

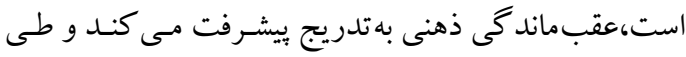
جند ماه آشكار مىشود(Y). در صورت عـدم درمـان(محود نمودن فنيل آلانين رزيم غذايى تحت نظر متخصص تغذيه و

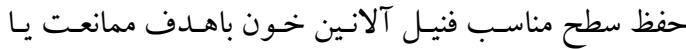

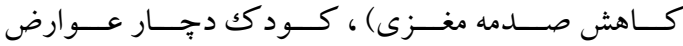
جبران نايذيرى همجِون صدمات مغزى مى شود.به ازاى هرماه

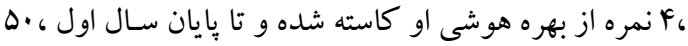
نمره از بهره هوشى را از دست مىدهد.عقب ماندكى ذهنى در اين بيمارى شديد است و كودكك مبتلا ،يرفعـاليتى همـراه با حر كات بىهدف بيدا مى كند(Y). تظاهرات بالينى بيمارى،

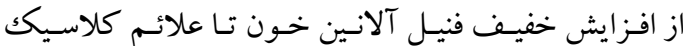
بيمارى همراه با افزايش واضـح فنيل آلانين خـون متفـاوت است(Y). در فنيل كتونورى ،رعايت رزيم بـهـدت محهدود

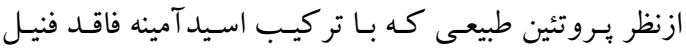
آلانين تكميل شود ، سبب جلو گيرى از عقبماندگى ذهنى

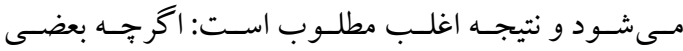

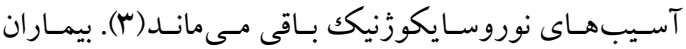
متابوليكك،بخش وسيعى از دانش بزشكى را در برمى گيرنــ.

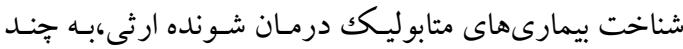
دليل مهم است. اول اينكه مىتواند منجر به درمان بيمار شود

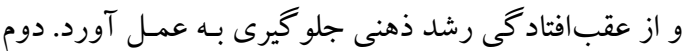

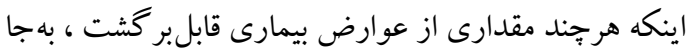
مانده باشد، درمان مى تواند بعضى از تصاوير و علائم بيمارى

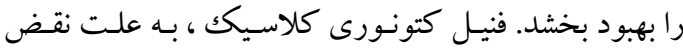
كامل فعاليت آنزيم فنيل آلانين هيدرو كسيلاز ايجاد مىشود فئد 


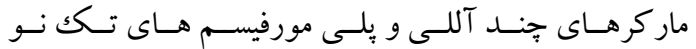

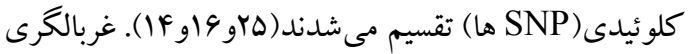

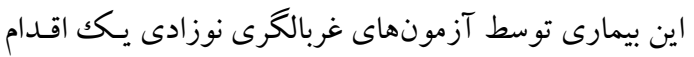
سـلامت اجتمـاعى اسـت كـه در ينجــاه سـال اخيـر انجـام مى شود(19). كسر هزينه -فايده غربالكرى فنيل كتونورى در بسيارى از كشورهاى تحليلشده اسـت و نشـاندهنــده فوايـــ

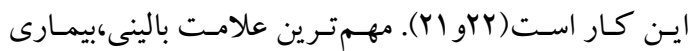
عقب ماندكى ذهنى است.افر اد مبتلا اساساً در مقايسه با گروه كنترل ازنظر نمره ضريب هوشى ، كلامسى ،تمر كز و كنترل موتور حر كتى متفاوت هستند(سM). ضـريب هوشى بيمـاران

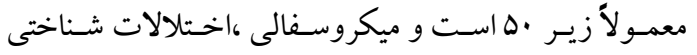
ناهنجارىهاى عصبى روانى و مشكلات روانى اجتمـاعى در اين بيماران بهوفور ديده مىشود. تشخيص بيمارى بـر اسـاس يـافتن سـطوح بـالاى فنيـل آلانسين در سـرم اسـت( (YF TF). محدوديت مصرف فنيل آلانين به كاهش سطح خـونى آن و ييشخيرى از اختلالات و آسيبهـاى مغزى در ايـن بيمـاران مىشود. بهترين بيش آكهى در كنتـرل سطوح فنيـل آلانين خون قبل از اولين مـاه تولـد اسـت (Yq). بـا توجـه بـه نكـات ذكرشده و اهميت اين بيمارى، مطالعه حاضر طراحى گرديد و ميانگين بهره هوشى دو گروه مورد( (PKU) و گروه شاهد

$$
\text { مورد بررسى قرار گرفت. }
$$

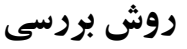

ايـن مطالعه از نـوع مطالعه كوهـورت- تـاريخى اسـت كـه جامعه مورد مطالعه كليه بيماران تحت معالجه و بالاى س سال مر اجعه كننده به درمانكاههاى PKU و غدد اطفال كه تحـت نظارت معاونت بهداشـتى دانشـاه علـوم بزشـكى كردسـتان بـوده اسـت، مـورد مطالعـه قـرار كرفـت. همجِنـين از ميـان كود كان سالم (از نظر ابتلا به فنيل كتونورى) مراجعـه كنتـده

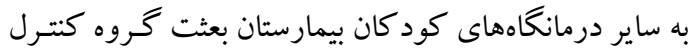

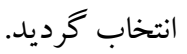
معيارهاى ورود مطالعه: كليـه كود كـان كـه در سـطح اسـتان يس از آزمون غربالخرى مثبت، توسط تست كرومـاتو گرافى
كشف زود هنگًام افراد مبتلا ،ضمن ايجاد اثرات مفيـد بـراى بيمـاران و افـزايش كيفيـت زنســـى آنهـا ،سـبب كـاهش

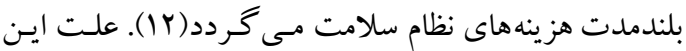
بيمارى با توارث اتوزوم مغلوب ،نقص در آنزيم كبدى فنيـل آلانين هيدرو كسـيلاز ( PAH:OMINr919) اسـت كه. خــود ناشسى از جهـش در زن PAH اسـت. ايسن آنـزيم در حضور كو فاكتور تتراهيدروبيويترن(BHF) باعـث تبـديل فنيل آلانين به L L - تيروزين مىشود. فراوانى ايسن بيمـارى در سفيديوستان حدود .... . 1: نفر در هر تولد زنـده اسـت. ولى اين ميزان از جمعيتى بـه جمعيـت ديخـر متفـاوت اسـت. فراوانى بيمارى PKU در جمعيت ايرانى ، انفر در هـ تولد زنده بر آورد شده اسـت كـه ايـن فراوانى بـالا بـه دليـل

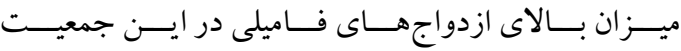

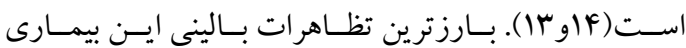
،عقبماندكى شديد ذهنى است. از ديخر علائم اين بيمـارى مى توان به حركـات غيـر هدفمنـد و غيـرارادى و تكانهـاى ريتميكك، نار احتى هاى بوسـى، اكزما،تشـنج و ميكروسـفالى اشاره نمود. تشخيص سريع بيمارى و شروع رزيسمدرمانى،بـه منظـور كنتـرل سـطح فنيـل آلانسين سـرم، در بيشـكيرى از

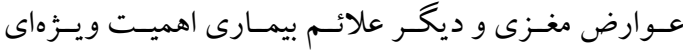

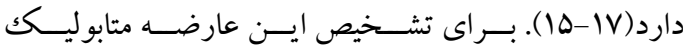
تست هاى مختلـف مورداسـتفاده قـرار مسى گيرنــ كـه تسـت

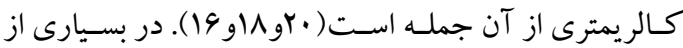
جمعيتهـاى مطالعهـ شـده، ·r موتاسـيون مـرتبط بـا بيمـارى PKU يـراكنش ايـن جهـشهـا در هـر جمعيـت متمـايز از جمعيـت ديخرى است. علاوه بر اين ،در هـر جمعيتى جنــ جهـش بـا فراوانسى بسـيار بــالا ديــده مسى شــود. اكثـــ بيمـار ان داراى

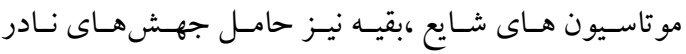
هستند(Y)-YY) . علاوه بر جهش هاى زن PAH تعدادى بلى مورفيسم نيز در اين زن موجـود اسـت كـه در كـار شناسـايى

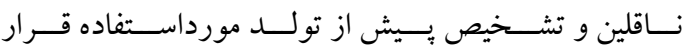

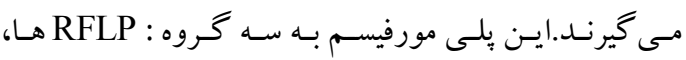


اساس تست هاى فر افكن، تحقيقات نشان داده انــ كـه تسـت آدمـك از حساسيت بـالايى برخـوردار است. ضرايب اعتبار

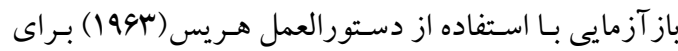
در حد متوسط (DAP)

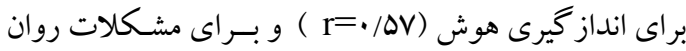

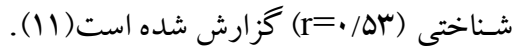

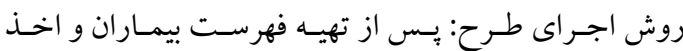
رضايت كتبى آكاهانه از والـدين كليسهى كود كـان شركت كت كنـــده در يـزٔوهش (كَروه هـاى مواجهـه و شـاهد) و انجـام

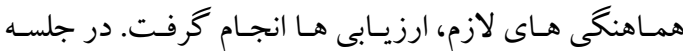
ارزيابى، آزمون تعيين سطح ضريب هوشى توسط متخصص روانشناسى اطفال انجام كرفت و داده ها با رعايـت امانـت و بدون ذكر نام بيماران جهت انجام آناليز جمع آورى گرديـد. به صورت همزمان گروهى بهعنـوان گَروه شـاهد نيز تحـت آزمون قرار گرفت. گروه شاهد شامل كود كانى سالم از نظر ابتلا به فنيـل كتونسورى و بـه صسورت تصـادفى و بـا رعايـت همسـان سـازى سـنى و جنسـى جهـت حـذف فاكتورهـاى مخدوش كننده، بود. داده هاى جمع آورى شده آناليز شد. روش تجزيـهو تحليـل دادههـا: يـس از جمـع آورى و وارد نمودن داده ها در نرم افزار SPSS نسخه آل، براى توصيف لجيف متغيرهاى كيفى از جـداول و نمودارهـا (فراوانى و درصـد)، ميانخين و انحر اف استاندارد، و براى تحليل متغيرهاى كمى از تى تست گرووه هاى مستفل و كاى اسكوار استفاده شد.

يافته ها نتايج مطالعه در جدول انشان داد؛ 19/V درصد افراد مـورد

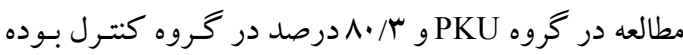

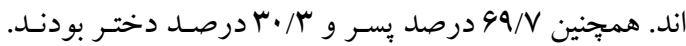
Fq/Y ، MN/F درصد شدت بيمارى متوسط و \$ ا درصـد شـدت بيمـارى شديد داشته اند. ميانگين سنى افراد مورد مطالعه س/ه/

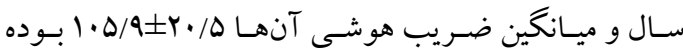
است.ضـمنا جنسـيت در گـروه هـاى مختلـف دار اى تفـاوت
سـرم بـه روش HPLC تشـخيص قطعسى داده شـده و از بــدو تولد تحت رزيم درمانى خاص PKU بوده انـد و اكنـون در

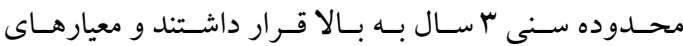
خروج:كود كانى كه به دليل تشخيص و درمـان ديـر هنگـام دجار كم توانى ذهنى شديد بودند، بهره هوشى كمتـر از •ه ه و نيز كود كانى كه سابقه ضربه به سر، مبتلابـه افـت شـنو ايى، حوادث زايمانى منجر به آسفكسى( آيگار پايين) بودند. حجـم نمونـه و روش نمونسه گيـرى: سا بيمـار مبتلابـه فنيـل كتونورى تحت درمان از ابتداى تولد در استان كردسـتان بـهـ صورت سرشـمارى در مطالعهـ وارد شـدند. همجنـين جهـت كروه كنترل، از ميان سه كودكك سالم از نظر ابـتلا بـه فنيـل كتونسورى مراجعـه كنـــه بـه درمانخـاه كود كـان بيمارسـان

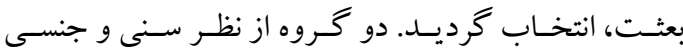
همسان سازى گر ديد. ابزار كردآورى اطلاعات: تسـت هوشىى گودينـاف: در بـين آزمونهاى ترسـيمى، آزمـون ترســيم آدمـك (DAM) از قدمت و شهرت بيشترى برخورداراسـت. گودينـاف بـراى سنجش هوشى كود كان س تا سا استفاده مىشود. ابن آزمـون

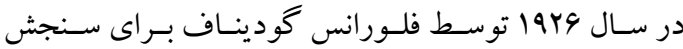
توانـايى هــاى شـناختى، ذهنـى و هـوش كود كـان بـه كـار

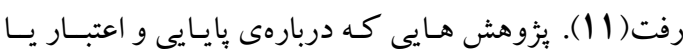
تائيد نتـايج آزمون ترسيم آدمكك انجامشدهاند بـه يافتههـاى بسيار رضـايت بخشى دست يافته اند تا جايى كـه مـك آور، بـر ايـن بـاور اسـت كـه ترسـيم آدمـك مى تواند بـه منزلـهى

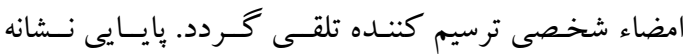
هـاى خـاص در آزمون ترسيم آدمـك بـر حسب مط مالعـات مختلـف نسـبتاً متغيــر كز ارش شــده اسـت. كاهيـل در سـال

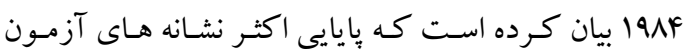

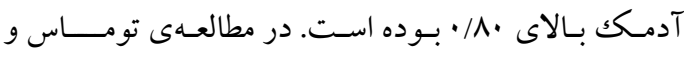
ويليــامز ضـــريب بِ يـــايى (همسانى درونى) بـا اسـتفاده از

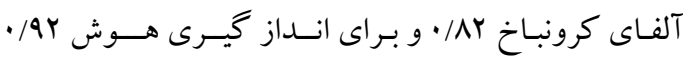

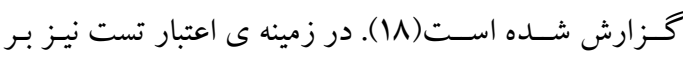




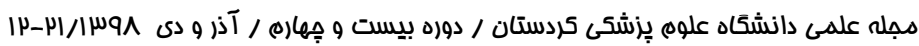

$$
\begin{aligned}
& \text { معنى دار نبود و بــه عبـارتى گـروه هـا از نظـر جــس همســان }
\end{aligned}
$$

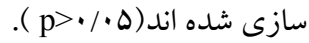

جدول ا. توزيع فراوانى و ميانگين و انحر اف استاندارد متغيرهاى موردمطالعه

\begin{tabular}{|c|c|c|c|c|c|}
\hline$P$ & & كنترل & $\mathrm{PKU}$ & \multicolumn{2}{|c|}{ متغير } \\
\hline \multirow[t]{2}{*}{$\cdot / I F V$} & \multirow[t]{2}{*}{$1 / 949$} & $(\%$ \% $/ \Lambda$ / $r q$ & $(\% \mid \Delta / Y) V$ & يسر & \multirow[b]{2}{*}{ جنسيت } \\
\hline & & $(\% v \cdot) \mid f$ & $(\% \mu \cdot) q$ & دختر & \\
\hline-- & -- & -- & $(\% F 9 / V) V$ & خفيف & \multirow{3}{*}{ شيمارى } \\
\hline-- & -- & -- & $(\% \mathrm{FG/V}) \mathrm{V}$ & متوسط & \\
\hline-- & -- & -- & $(9 / V) 1$ & ش شيد & \\
\hline $\mathrm{P}$ & $\mathrm{T}$ & انحراف معيار)ميانگين & (انحر اف معيار)ميانگين & & \\
\hline.$/ 1 Y G$ & $-1 / \Delta F Q$ & $\varphi / \Delta \wedge(Y / \backslash \Delta)$ & $\Delta / \Gamma \wedge(\Gamma / 9 q)$ & & \\
\hline
\end{tabular}

جدول شماره Y نشان داد بين ميانگين ضريب هوشى افراد در دو گروه مورد مطالعه تفاوت معنادار آمارى وجود نداشت، هر جند در كروه كنترل بالاتر بود(4)

جدول r. مقايسه ميانگين ضريب هوشى افراد در دو گروه مورد مطالعه

\begin{tabular}{|c|c|c|c|c|c|c|}
\hline $\mathrm{p}$ & $\mathrm{t}$ & فاصله اطمينان در سطح ه9٪٪ & درجه & ميانگين و انحر اف & تعداد & كروه ها \\
\hline .1 .9 & $-1 / 19$. & $(-Y Y / Y \Lambda-\cdot / \cdot / \Delta Y)$ & $g F$ & 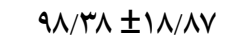 & ir & مورد (PKU) \\
\hline & & & & 1.N/TrEIr/RV & $\Delta \mu$ & شاهد \\
\hline
\end{tabular}


نداشت (P=.91.91)، تفاوت بين ميـانخين هـا از نظر آمـارى معنى دار نبوده است. كرامتى و همكاران، تأثير سن شروع و

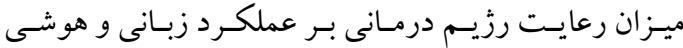

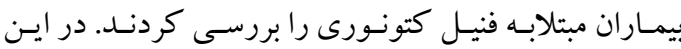
مطالعه الب بيمار مورد مطالعه قرار گرفت. تمامى گرووه هـاى فنيـل كتونـورى در بهرههـاى هوشى و زبـانى در مقايسهـ بـا

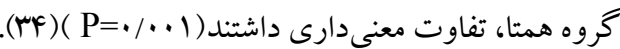
در يكك مطالعه مرورى، عملكرد اجر ايى در كود كان مبتلابه. فنيل كتونورى با درمان زودهنكام را موردبررسى قرار دادند.

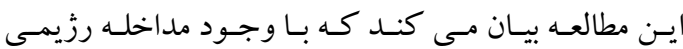

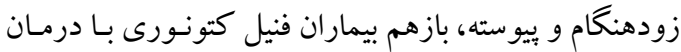

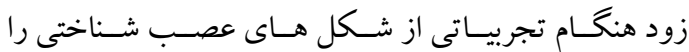
دارند(צ). ناحيه ایى از توانايى شـناختى كـه اعتقاد بـر ايـن است كه در خير مىشـود، عملكرد اجر ايسي ( executive (EF) است. بيشترين در گيرى عملكرد اجر ايسى (function كـه طـى مطالـهـ مشـخص شــ، مربـوط بـه حافظـه كـارى اجرايى(executive working memory) و نيـروى باسـخ بازدارنسـه(prepotent response inhibition) بـود.

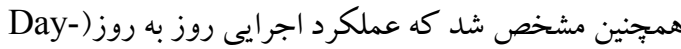

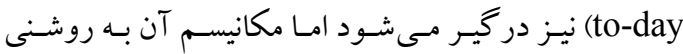

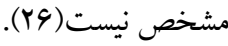

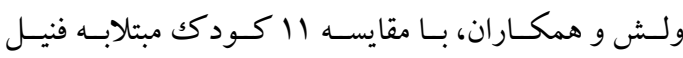
كتونورى زود درمـان شـده (در سـنين يـيش دبستانى) و 11 كودكى طبيعى، اختلالاتى در كار كردهـاى اجرايسى گرووه

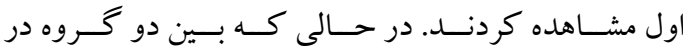
كار كردهاى غير اجرايى (از جمله كاركردهـاى وابسته بـه

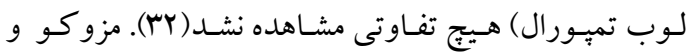
همكاران نيز در مطالعه اى روى كود كان مبتلابه PKU كـه زود و در سنين مدرسه ( 4 تا لا سـال) درمـان شـده بودنـد،

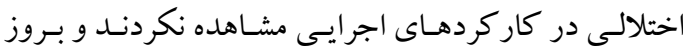

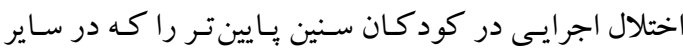

نتايج مطالعه حاضر نشان داد؛ در بين نمونه هاى مورد مطالعهـ

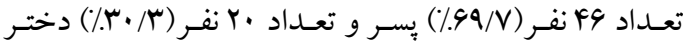

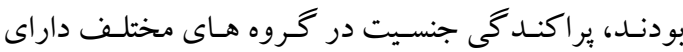

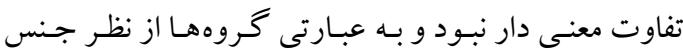

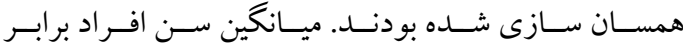
بـا بr/M حداكثر 19 سال بود. شدت بيمارى در بين نمونه هاى مربوط به گروه PKU در سه دسته خفيف، متوسط و شـديد دسته

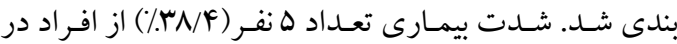

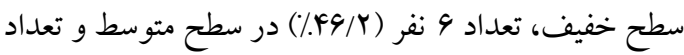
r نفر (\$ه/\&\%) در سطح شديد قرار داشتند. در مطالعه همتى يور و همكاران از FF بيمار مورد مطالعه YV نفر (T/Y

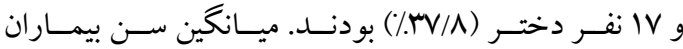

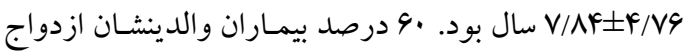
فاميلى داشتهاند. از نظر سن در زمـان تشـخيص بـدو تولـد، بـ

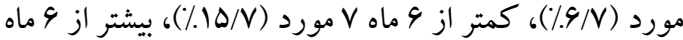
ها مورد (NV/N/) بوده است. در اين مطالعه اختلاف آمـارى

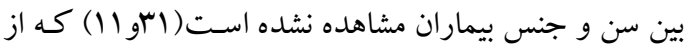
نظر عـدم تفـاوت معنى دار سـن و جـنس بـا مطالعه مـا هـم خوانى داشته اسـت. در مطالعه بـديعى اول و همكاران؛ 1 بيمار مبتلا به فنيل كتونورى در دانشكاه علوم بزشكى مشـهد ثبت شده بود كه از اين تعداد يكك نفر فوت كرده و برونـده

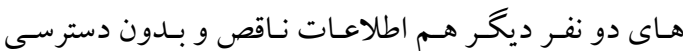

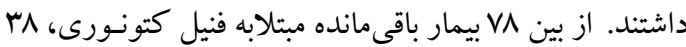

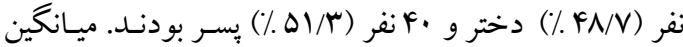

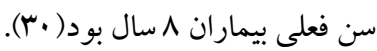

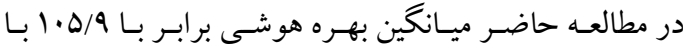

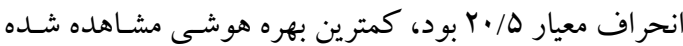

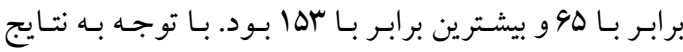

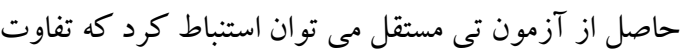

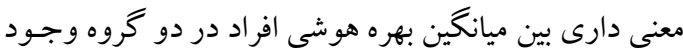


مقايسه بهره هوشى بر حسب جنسيت با هـم همخـوانى نـدارد

$$
\text { اما برحسب سن هم سو با هم بوده است. }
$$

در مطالعـه كرامتسى و همكـاران ،تـأثير سـن شـروع و ميـزان رعايت رزيسم درمـانى بـر عملكـرد زبـانى و هوشى بيمـاران مبتلابه فنيل كتونورى را بررسى كردنــ. تمـامى گَروه هـاى فنيـل كتونسورى در بهـرههـاى هوشى و زبـانى در مقايسـه بـا

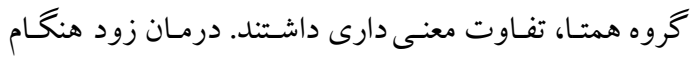
باعث ايجاد افزايش معنى دارى در بهره هاى هوشى و زبـانى در مقايسـه بـا درمـان ديرهنگ حداكثر تا قبل از يـك سـالكى باعـث ايجـاد افزايش معنىى دارى در تمامى مهارت ها به جز هوش عملـى، در مقايسـه بـا

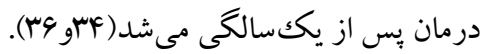

\section{نتيجه كيرى}

در اين مطالعه مشاهده شد كه بهره هوشى كود كـان مبـتلا بـه فنيل كتونورى از نظر آمارى اختلاف معنى دارى با كود كان

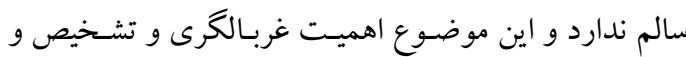
درمان مثمر ثمر را نشان مى دهد.

\section{تشكر و قدردانى}

از شوراى يُزوهشى دانشكده يزشكى به خـاطر تصـويب ايـن طرح تشكر و قدردانى مى شود و همجنين، از خانو اده محترم نمونه هاى مورد مطالعه به خاطر همكارى در اجراى طرح نيز تشكر و قدردانى مى گردد. در ضمن، اين مقاله از يا يـاننامـهـ

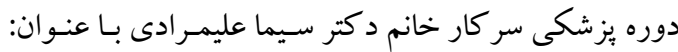
"ابررسى مقايسه نمـرات بهـره هوشى كودكـان مبتلابـه فنيـل كتونسورى بـا كود كـان سـالم مر اجعـه كنـــده بـه درمانكـاه بيمارستان بعثت سنتدج در سال MaV|(1) استخر اج شده است.
مطالعات به دست آمده بود، به تأخير تكـاملى ايـن كودكـان مربوط دانستند(سM).

در مطالعه ما كمترين ميـانكين بهره هوشى در گرووه PKU مربوط به كود كانى است كه بيمارى آن در وضعيت متوسط بود و بيشترين بهره هوشى در ايسن گـروه مربـوط بـه افرادى است كه بيمارى آنان بهصورت خفيف بوده اسـت و تفـاوت

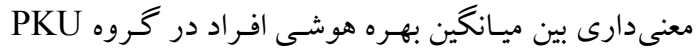

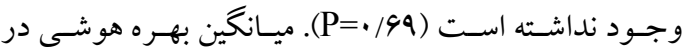
مطالعه همتى بور و همكاران كمترين بهـره هوشى در گرروه مربـوط بـه فـردى اسـت كـه بيمـارى آن در وضـعيت PKU شديد بود و بيشـترين بهـره هوشسى در ايسن گـروه مربـوط بـهـ افـرادى اسـت كـه بيمـارى آنـان بـهـــورت خفيـف بـوده است(Yq). در مطالعه ما كود كان مورد مطالعهـ در بــدو تولـد توسط تست كالريمترى غربالكرى شده و تحت درمـان قـرار كرفته اند ولى در مطالعه همتى يـور VV/A ٪ كود كـان مـورد مطالعه بعد از شش ماه بيمارى آنها تشخيص داده شده است و تفاوت در نتايج ضـريب هوشى برحسب شـدت بيمـارى ممكن است به زمان تشخيص بيمارى مربوط بوده باشد.

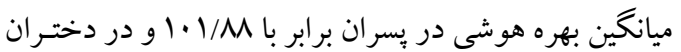

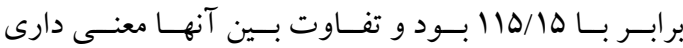
بود(10 (P=(P)، تفاوت بين ميانگين ها نشان داد كه ميانگين بهره هوشى در دختـران بـالاتر از يسـران بـوده اسـت. نتـايج حاصل از آزمون ضـريب همبســـى بيرسـون نشـان داد كـه ارتباط معنى دارى بين ميانكين بهره هوشى افر اد بـا سـن آنـان

$$
\text { وجود نداشته است(به (P=/ (P). }
$$

1. در مطالعه تهر انى دوست و همكاران گروه مـورد، شـامل فرد (1 دختر و Y يسر) مبتلا به PKU (تحت درمان) و گروه كنترل ها نفر (rا دختر و بّ يسر) بود. از نظر سن و جــس و بهـره هوشـى بـين دو گـروه اخـتلاف معنسى دارى مشـاهده نشد(ه). نتايج مطالعه حاضر با مطالعه تهر انى دوست از نظر 


\section{References:}

1.Williams, R.A., C.D. Mamotte, and J.R. Burnett, Phenylketonuria: an inborn error of phenylalanine metabolism. The Clinical Biochemist Reviews, 2008. 29(1): p. 31.

2.Moradi, K. and R. Alibakhshi, High risk of birth defects with PKU in Mast-e Ali village, Kermanshah province. Journal of Kermanshah University of Medical Sciences (J Kermanshah Univ Med Sci), 2014. 18(1): p. 62-65.

3.Van Spronsen, F., M. Hoeksma, and D.-J. Reijngoud, Brain dysfunction in phenylketonuria: is phenylalanine toxicity the only possible cause? Journal of inherited metabolic disease, 2009. 32(1): p. 46.

4.Moradi, P., et al., Distribution Occurrence of Phenylketonuria in the World: A Systematic Review and Meta-Analysis. Depiction Health, 2016. 6(4): p. 1-12.

5.Gu, X. and Z.G. Wang, Screening for phenylketonuria and congenital hypothyroidism in 5.8 million neonates in China. Zhonghua yu fang yi xue za zhi [Chinese journal of preventive medicine], 2004. 38(2): p. 99-102.

6.Rivera, I., et al., Population genetics of hyperphenylalaninaemia resulting from phenylalanine hydroxylase deficiency in Portugal. Journal of medical genetics, 1998. 35(4): p. 301-304.

7.Seymour, C., et al., Newborn screening for inborn errors of metabolism: a systematic review, in Database of Abstracts of Reviews of Effects (DARE): Quality-assessed Reviews [Internet]. 1997, Centre for Reviews and Dissemination (UK).

8.Dos Santos, L.L., AS Bases Moleculares DA Fenilcetonúria No Estado De Minas Gerais. 2007, Universidade Federal De Minas Gerais.

9.Ordooei, M., et al., Anemia in Patients with Phenylketonuria in Yazd. Iranian Journal of Pediatric Hematology and Oncology, 2012. 2(2): p. 27-77.

10.Habib, A., et al., Incidence of phenylketonuria in Southern Iran. Iranian Journal of Medical Sciences, 2015. 35(2): p. 137-139.

11. Farhadi Ali,. Pouraatmad Aggression Symptoms in Dodgers Painting Test in 9 Year Old Boys.

Principles of Mental Health.2008,3(10):199-207

12.Hatam, N., et al., Cost Utility of Neonatal Screening Program for Phenylketonuria in Shiraz University of Medical Sciences. 2014.

13.da Silva, L.C.S., et al., Molecular characterization of phenylketonuria in South Brazil. Molecular genetics and metabolism, 2003. 79(1): p. 17-24.

14.Kim, S.-W., et al., Structural and functional analyses of mutations of the human phenylalanine hydroxylase gene. Clinica chimica acta, 2006. 365(1-2): p. 279-287.

15.Erlandsen, H., et al., Structural studies on phenylalanine hydroxylase and implications toward understanding and treating phenylketonuria. Pediatrics, 2003. 112(Supplement 4): p. 15571565.

16.Koochmeshgi, J., A. Bagheri, and S. Hosseini-Mazinani, Incidence of phenylketonuria in Iran estimated from consanguineous marriages. Journal of inherited metabolic disease, 2002. 25(1): p. 80-81.

17.Kozák, L., et al., Phenylketonuria mutations and their relation to RFLP haplotypes at the PAH locus in Czech PKU families. Human genetics, 1995. 96(4): p. 472-476.

18.Lee, D.H., et al., The molecular basis of phenylketonuria in Koreans. Journal of human genetics, 2004. 49(11): p. 617.

19.Aulehla-Scholz, C. and H. Heilbronner, Mutational spectrum in German patients with phenylalanine hydroxylase deficiency. Human mutation, 2003. 21(4): p. 399-400.

20.Mallolas, J., et al., Mutational spectrum of phenylalanine hydroxylase deficiency in the population resident in Catalonia: genotype-phenotype correlation. Human genetics, 1999. 105(5): p. 468473.

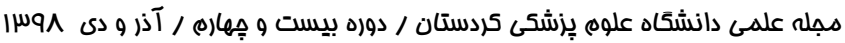


IM بررسى دقايسم نمرات بعره هوشى...

21.Lee, Y.-W., et al., Mutation analysis of PAH gene and characterization of a recurrent deletion mutation in Korean patients with phenylketonuria. Experimental \& molecular medicine, 2008. 40(5): p. 533.

22.Bercovich, D., et al., A mutation analysis of the phenylalanine hydroxylase (PAH) gene in the Israeli population. Annals of human genetics, 2008. 72(3): p. 305-309.

23.Miller, S., D. Dykes, and H. Polesky, A simple salting out procedure for extracting DNA from human nucleated cells. Nucleic acids research, 1988. 16(3): p. 1215.

24.Madden, M., Phenylketonuria: Defects in amino acid metabolism. Mol Med (SCJMM), 2004. 5: p. 57-61.

25.Kim, W., et al., Trends in enzyme therapy for phenylketonuria. Molecular Therapy, 2004. 10(2): p. 220-224.

26.Christ, S.E., et al., Executive function in early-treated phenylketonuria: profile and underlying mechanisms. Molecular Genetics and Metabolism, 2010. 99: p. S22-S32.

27.Setoodeh, A., et al., Tetrahydrobiopterin responsiveness in a series of 53 cases of reports, 2015. 2: p. 77-79.

28.Ghadbeigi Z, Sajedi F, Biglariyan A, Movallali G, Nazi S. Evaluation of Personal-Social Developmental Skills Levels in Children with Early Treated Phenylketonuria. jrehab. 2013; 14 (2) : $46-53$

29. Scriver, C.R., The PAH gene, phenylketonuria, and a paradigm shift. Human mutation, 2007. 28(9): p. 831-845.

30. Badiee, S. Morovatdar,N . Hossini; S.M.R. Norouzi,F. Mina,T. Epidemiological and clinical study of phenylketonuria (PKU) disease in Khorasan Province; Northeast Iran.2014,57(3): 571-578

31. Hemmatipour,A ,. Alijan, H. Aminzadeh ,M., Hakim,A. The study of parental knowledge of children with phenylketonuria. Nursing Journal of the Vulnerable. 2017; 4(11): 1-12.

32.Welsh, M.C., et al., Neuropsychology of earlytreated phenylketonuria: Specific executive function deficits. Child development, 1990. 61(6): p. 1697-1713.

33.Mazzocco, M.M., et al., Cognitive development among children with early-treated phenylketonuria. Developmental Neuropsychology, 1994. 10(2): p. 133-151.

34. Karamati,N., Soleimani ,Z., Alaei,M.R,. Rouhani, R. The effect of age and the degree of observance of the regimen on linguistic and intelligence performance of patients

With phenylketonuria. Audiology,2014 .22(3).

35. Tehrani Dost.M., Azadi,B.M.,Sedigh,A., Ashrafi,M.R,. Abubindarad,J,. Disorders of executive function in patients with phenylketonuria treated. New Cognitive Science, 2007, 7(1).

36. Rahmani K, Yarahmadi S, Etemad K, Mehrabi Y, Aghang N, Koosha A, Soori H. Intelligence Quotient at the Age of Six years of Iranian Children with Congenital Hypothyroidism. Indian pediatrics. 2018 Feb 1;55(2):121-4. 